Article

\title{
Earth Observation Techniques to Assess Water Quality Moni- toring in the Murray Darling Basin of Australia
}

\author{
A. Forghani ${ }^{1,2,}$, M.A. Islam ${ }^{3}$, S. Kazemi ${ }^{3}$ \\ ${ }^{1}$ Science, Technology, Engineering and Mathematics (STEM), University of South Australia (UniSA), Adelaide, \\ Australia \\ ${ }^{2}$ Faculty of Science \& Technology, University of Canberra (UC), Canberra, Australia \\ ${ }^{3}$ Murray Darling Basin Authority, Canberra, Australia \\ * Correspondence: a.forghani@unisa.edu.au
}

How to cite this paper: Forghani, A., Islam, M., \& Kazemi, S. (2021). Earth Observation Techniques to Assess Water Quality Monitoring in the Murray Darling Basin of Australia. World Journal of Geomatics and Geosciences, 1(1). DOI:

10.31586/wjgg.2021.010102. Retrieved from https://www.scipublications.com/journal/in-

dex.php/wjgg/article/view/51

Received: June 6, 2021

Accepted: July 19, 2021

Published: July 21, 2021

Copyright: (C) 2021 by the authors. Submitted for possible open access publication under the terms and conditions of the Creative Commons Attribution (CC BY) license (http://creativecommons.org/licenses /by/4.0/).
Abstract: The Murray Darling Basin Authority (MDBA) currently has been using a discrete field sampling technique for water quality monitoring that is expensive, time consuming and may not adequately represent the spatial variability of water quality relative to the entire water body. A pilot project was executed to assess the effectiveness of using earth observation data, supported by archived field-based observations for quantitative estimation of Water Quality Parameters (WQP) and detection of algal blooms in the River Murray. The selected pilot study area includes a $100 \mathrm{~km}$ stretch of the River Murray between the Hume Dam and Yarrawonga Weir. The time frame for the archived field samples was between November 2008 and March 2011, when major algal blooms were occurring in this stretch of the Murray River.Analysis of the 2009 data shows that waters in sites in the Murray River downstream of the Hume Dam to the Yarrawonga Weir show more temporal than spatial variability in Chl-a and PC levels. The Chl-a concentration is relatively less in the Yarrawonga Weir than in the Murray River. The scatter plot of PC vs. Turbidity suggests that PC is a more significant parameter for the detection of Cyanobacteria than $\mathrm{Chl}-\mathrm{a}$. The field data represents the temporal bio-optical variability across the 2009 algal bloom events by successfully capturing the co-variations among Chlorophyll-a, Chycocyanin and turbidity at pre, during and post bloom conditions. The methodology has proved that the usefulness of an integrated earth observation and field based WQP technique to accurately map algal bloom events. The long term MDBA RMWQMP data for the 2009 bloom event is found partially compatible to the NOW Pilot study data in that only the data for the Heywood site that was used together for testing the WQP monitoring technique. The incompatibility of the RMWQMP data downstream of Yarrawonga Weir may be due to differing techniques used for determining Chlorophyll. The 2010 data was suitable for testing the technique for complex spatial bio-optical variability during the peak of the bloom in a large water storage. Lack of Chlorophyll measurements in 2010 data poses challenges in interpreting the relationship of bio-optical variability with the spatial distributions of bio-optical parameters. As relational parameters are absent, local information and expert advice will be required to develop plausible assumptions between the Chlorophyll - Phycocyanin relationship. The field sampled data for the 2010 bloom event acquired from the Hume Dam was used for comparative investigation of both moderate resolution sensors (MODIS and MERIS) and high resolution sensors (TM/TM+). The 2009 bloom event field samples of sites in the Yarrawonga Weir was used as an input with MODIS and MERIS and the data from all the sites was applied with TM/TM+. This paper will present an integrated earth observation and field based WQP technique to accurately map algal bloom events, and discuss challenges for real time earth observation data initiatives and future collaborative projects.

Keywords: Earth observation, Water quality, MDBA, Landsat, MODIS, MERIS, PC, Chl, Algal bloom

\section{Introduction}


The Murray-Darling Basin (MDB) covers an area of over 1 million square kilometres, comprising roughly $14 \%$ of the total area of Australia. The vast majority of the Australian continent is classified as dry to semi-arid, with prolonged periods of drought and occasional heavy rainfall resulting in devastating floods.

The MDB is home to rivers and waterways totalling more than 15,200 kilometres in length. These rivers and tributaries are generally narrow $(50-100 \mathrm{~m}$ wide) and shallow. A number of large dams, reservoirs and weirs were constructed to store water and regulate flows in the Murray and Darling Rivers and their tributaries.

The Murray and Darling Rivers are the life blood of the regional towns that are located on them. Apart from regulation providing available water for stock, domestic, industrial and agricultural purposes, it provides an amenity for recreational pursuits.

The increase in the rate of supply of organic matter in an ecosystem or eutrophication [1] can lead to increased growth of algae. As algae die and decompose, nutrients, in particular phosphates and nitrates, increase in the water body leading to reduction of dissolved oxygen and water quality, which in turn can lead to fish death or reduced value to fishing and recreational use of water ways. Human activities such as run-off from agricultural fertilizers and unprocessed sewage can also contribute to eutrophication.

The Murray River and its tributaries have long been subject to problems with cyanobacteria. In the past few years in particular, reduced water levels due to prolonged drought across the whole Murray Darling Basin have fostered an increase in cyanobacteria, leading to an explosion of phytoplankton populations in many storages ([2-4]). According to s172 of The Water Act 2007, the MDBA has a critical requirement for the management of water quality and water dependent ecosystems associated with Basin water resources. The River Murray Water Quality Monitoring Program (RMWQMP) has collected discrete field sampling of physical, chemical and biological parameters from 35 sites since 1978 to determine and monitor long term water quality variations. On 5 March 2009 a bloom was detected on Lake Hume, and by 6 April the red alert had extended to cover $800 \mathrm{~km}$ of the Murray River downstream of the Hume Dam [2]. Between 8 and 10 February 2010 a substantial cyanobacterial bloom dominated by Anabaena Circinalis was detected from Lake Hume to $400 \mathrm{~km}$ downstream of the Hume Dam, although in lesser concentration [5].

With the recent outbreak of blue-green algal (cyanobacteria) blooms, the RMWQMP has taken the initiative to rapidly respond to these events, using aerial surveillance to report on the extent of the algal bloom and help inform management decisions. Rapid sampling capability for surveying and monitoring of blue-green algal blooms in the MDB was initiated and a pilot survey, which used rapid broad-area sampling for water quality, was conducted in April 2010 in Lake Hume [5].

While WQPs derived from a field sampling are more accurate than those determined by other means (including remote sensing and computer modelling), field sampling represents the water quality of a very small area spatially, and is time consuming and expensive to collect. Therefore, discrete field sampling does not adequately represent the spatial variability of water quality and often does not represent the condition of the entire water body [6]. Moreover, water quality monitoring of a large system such as the MDB using discrete field sampling alone would be extremely difficult and prohibitively expensive.

The water quality parameters were extracted through a combination of multiplatform remote sensing datasets, and has been validated using co-temporal in situ measurements collected during field campaigns that produced quite satisfactory results over inland shallow waters in Spain. In particular, for the drone hyperspectral instrument, the root means square error, computed to quantify the differences between the estimated and in situ chlorophyll-a concentrations, was 3.45 with a bias of 2.96 [7]. Earth observation data combined with limited in-situ field data sampling can provide a quick assessment of surface water quality. The synoptic and repetitive viewing capabilities of satellite earth observation data would overcome constraints associated with field sampling, providing 
an additional means of water quality monitoring over a greater range of temporal and spatial scales $[8,38]$.

This paper describes a pilot study of water quality monitoring using satellite earth observation undertaken collaboratively by the MDBA. The objective of this study was to investigate the capability of earth observation data for estimating bio-optical WQPs using archived field sampled water quality data and determine its suitability for detecting and tracking algal bloom events in the study area. In this study, only archived field sample data was analysed. The results of this analysis, its implication for the selection of a satellite sensor and the methodology of generating WQP for the pilot study are described.

\section{Study Area and the River Murray Water Quality Monitoring Program (WQMP)}

The area selected for the pilot study includes a $100 \mathrm{~km}$ stretch of the River Murray between the Hume Dam and Yarrawonga Weir as shown in Figure 1. Algal blooms have frequently occurred in this area ([2-4]) prompting several jurisdictional agencies to undertake field sampling for WQPs within this reach. Field sampling of WQPs was performed at regular intervals during the entire period of the pilot study.

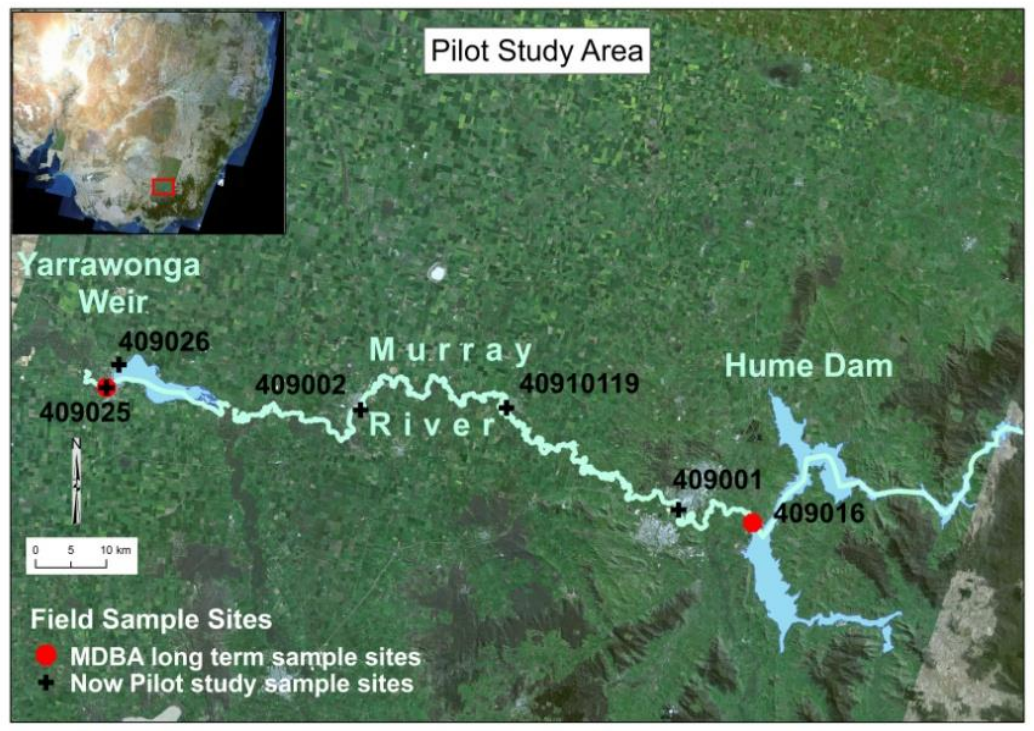

Figure 1. Pilot Study area and the sample site locations.

Among the jurisdictional agencies, the field sampling program being carried out by the NSW Office of Water (NOW) is of significant importance to this study. NOW is carrying out bi-weekly to monthly field sampling of algal parameters from 8 sampling sites since January 2008 for detecting algal blooms and taking various management actions (e.g. providing water level alerts to water users). The NOW carried out additional sampling of bio-physical WQPs between November 2008 and May 2009 using an in-situ measuring fluorometer to trial rapid sampling as opposed to laboratory analysis of the samples. These fluorometric measurements were carried out at five sampling sites in the Murray River downstream of Hume Dam.

\section{Data and Methodology}

The proposed methodology broadly involves four key steps: analysis of the archived field sample data, atmospheric correction of earth observation imagery, development and verification of a spectrally-stratified WQP algorithm and application of the algorithm for WQP mapping ([10,11,36,38]).

\subsection{Field Sample Data Collection}


The archived WQP data sets includes MDBA Pilot Study (MDBAPS) data, MDBA long term monitoring data acquired by NOW(MDBA_NOW) and by Department of Sustainability and Environment, Victoria (MDBA_DSE) and NOW Pilot Study (NOWPS) data. The MDBAPS and NOWPS data sets were obtained from pilot studies undertaken to develop a rapid field sampling capability using an in-situ measuring fluorometer.

With the MDBA_NOW data; turbidity was measured in-situ and Chl-a (Chl-a) concentration was determined from the surface grab samples in the laboratory using UNESCO [11] and Lorenzen [12] spectro-photometric techniques.

The MDBAPS used a Hydrolab MS5 system for measuring $\mathrm{pH}$, turbidity and temperature and a Turner Cyclops-7 fluorometer for measuring cyanobacterial concentrations [5]. The NOWPS used a Yellow Spring Instrument (YSI) water quality sonde for measuring temperature, turbidity, PC (PC) and Chl-a [2]. The measurements made by these instruments were calibrated and verified using surface grab samples.

\subsection{Field Sample Data Analysis}

The analysis of archived field sample data involves summarising the available archived data and the analysis of various scatterplots. Available archived field samples were summarised by period of acquisition, measured WQPs and number of observations for each dataset. This information was used to check the number of archived satellite images available close to the field sampling area.

Scatterplot analysis was performed to determine the spatial and temporal variability of distributions of optically active in-water constituents, their effect on the optical property of the water, and suitability for collective use of the datasets obtained across multiple agencies for the study.

Spatial variability of a data set observed from relatively few sample sites were determined by comparing site-wise scatterplots and from large number of sample sites. This was done by splitting the samples site into small transects along North to South and East to West directions and comparing transect-wise scatterplots. Relationship between scatterplot and spatial distribution of the samples in these transects are analysed using scatterplot and the map showing the spatial distribution of transects. For clearer understanding of the relationship same colour scheme was used for representing the samples in the scatterplot and in the transect map.

The suitability of collective use by multiple agencies was also carried out by comparing scatterplot distributions of the sampled in water constituents and optically active water quality parameters.

\subsection{Selection of Archived Satellite Sensor Images}

Earth observation archives were searched to obtain cloud free satellite images, suitable for monitoring water quality within the MDB during the relevant time span and close to the acquisition dates of the field sampled datasets. A summary of these images is provided in Table 2.

Table 1. Summary of archived satellite images acquired close to the field sample acquisition date: Field sampled Set 1 was acquired on November 2008 to May 2009 and Set 2 was acquired on 10-13 March 2010.

\begin{tabular}{|c|c|c|}
\hline $\begin{array}{c}\text { Satellite Sensor/Area of } \\
\text { coverage }\end{array}$ & \multicolumn{2}{|c|}{$\begin{array}{c}\text { Number images available for different time frame } \\
\text { Matching field sampled datasets }\end{array}$} \\
\cline { 2 - 3 } & Set 1 & Set 2 \\
\hline MERIS & 15 & 1 \\
\hline MODIS & 16 & 1 \\
\hline TM/ETM+ & 19 & 1 \\
\hline
\end{tabular}


The estimation of bio-optical parameters (such as Chl-a and PC) for the detection of algal blooms in inland waters has demanding requirements for instrumentation in terms of spectral resolution and sensitivity, atmospheric correction accuracy and water constituent retrieval algorithms [14].

Many 'ocean-colour' satellite sensors are available today such as MODIS, SeaWiFS, OCM and MERIS. MERIS offers the most suitable option for real-time operational and detailed parameter retrieval of inland waters, because of its high temporal resolution (2-3 days) and spectral coverage of 15 bands in the visible and near IR, providing basin wide coverage. However, because of its relatively coarse spatial resolution $(300 \mathrm{~m})$ it is best utilized for larger water bodies such as lakes, dams, and reservoirs [8]. Monitoring of large water bodies in the MDB is also very important because lakes and storages provide a favourable environment for phytoplankton growth and algal blooms [15].

The Moderate Resolution Imaging Spectroradiometer (MODIS) sensor on board the TERRA and AQUA satellites provides a high temporal resolution. MODIS sensors on TERRA and AQUA satellites provide daily images in the morning and afternoon around $3 \mathrm{hrs}$ apart [14]. Therefore, it is worth investigating the MODIS 250-500m images for this study because large numbers of relevant images are available close to the acquisition of archived data (Table 1). MODIS's two broad high-resolution bands (250m) have been used successfully for monitoring Total Suspended Sediments (TSS) and turbidity in inland lakes and estuaries $([17,18,19,37])$. However, its ability to detect other crucial parameters, such as phytoplankton pigments (Chl-a), is limited. It is worth noting that MODIS 500m bands shows potential for Chl monitoring in coastal waters ([20,22,24]).

Higher resolution satellites are required for monitoring the narrow rivers characteristic of the MDB. Landsat provides the best choice for this purpose, as data is available free of charge. When data from Landsat TM5 and TM7 is combined, two images can be obtained every 16 days [23]. In one part of the study area (from the Hume Dam to around $15 \mathrm{~km}$ downstream) the Landsat paths (91 and 92) overlap, allowing the capture of $4 \mathrm{im}$ ages every 16 days.

\subsection{Atmospheric Correction}

An accurate atmospheric correction technique is required to use a collection of archived field data for the development of robust bio-optical algorithms. In atmospheric correction, the atmospheric scattering effects are removed from the total radiance measurement by the radiative transfer model. Atmospheric effects increase with off-nadir viewing as the thickness of the atmosphere between the target and the sensor increases. This aspect is particularly important for wide field-of-view sensors such as MODIS and MERIS [24].

Table 2. List of atmospheric correction softwares

\begin{tabular}{|c|c|c|c|}
\hline Software Name & $\begin{array}{c}\text { Agency that devel- } \\
\text { oped the software }\end{array}$ & Supporting Sensor Image & Software suitable for: \\
\hline SeaDAS & NASA & MODIS and MERIS & $\begin{array}{c}\text { Oceanic and Coastal Environ- } \\
\text { ment }\end{array}$ \\
\hline BEAM & ESA & MERIS & $\begin{array}{c}\text { Oceanic and Coastal Environ- } \\
\text { ment }\end{array}$ \\
\hline ENVI, FLAASH & ITT VIS & Landsat & Terrestrial environment \\
\hline ATCOR & ERDAS & Landsat & Terrestrial environment \\
\hline
\end{tabular}

This study intends to evaluate both land-based and coastal water-based atmospheric correction software packages to select the technique best suited to correction of images over inland waters. 
The raw MODIS data will be atmospherically corrected using the SeaDAS software package and shall be compared against similar MODIS data that Geoscience Australia (GA) had atmospherically corrected using MOD09-MOD43 Land-based atmospheric correction software. MDBA has engaged Prof Arnold Dekker from the CSIRO Land and Water's Environmental Earth Observation Program to conduct the following professional services for this project:

- $\quad$ Produce approximately 22 atmospherically corrected Landsat scenes and relevant (near-coincident) MERIS and MODIS scenes using CSIRO c-WOMBAT-c (MODTRAN - based) code (for Landsat), and the VISAT-BEAM software (MERAIS) for the Authority.

- Share expertise through hosting appropriate Authority NRI staff at a CSIRO facility.

- $\quad$ Provide appropriate access to Geoscience Australia NBAR products for the same 22 Landsat scenes referred to in (a) which CSIRO holds for use by the Authority.

- Provide Ensure that MDBA with the atmospherically corrected Landsat and MERIS satellite images.

- $\quad$ MDBA will negotiate suitable end-user license agreements with Geoscience Australia (for NBAR corrected Landsat data and with the European Space Agency (for MERIS images) to have free access to the CSIRO corrected data as the Authority does not have relevant atmospheric correction software in-house to perform the required image processing.

For MERIS data, BEAM softwares would be used for atmospheric correction and would be compared with the European Space Agency (ESA) corrected product.

For Landsat images, land-based, atmospherically corrected GA images [25] would be evaluated against a similar CSIRO product. The CSIRO corrected product is generated via a technique developed exclusively for correction of images over inland aquatic environments.

\subsection{Development and Validation of WQP Algorithms}

In this study statistical correlation and regression analysis would be performed to develop the WQP algorithm. Existing algorithms, developed for accurately retrieving WQP from various sensors as reported in the literature (Table 3), would be used as guidelines to select the appropriate bands and band transformations for the retrieval of these parameters.

Table 3. Summary of semi-empirical bio-optical algorithms for MERIS and Landsat ( $K$ in the table denotes the central wavelength of image bands).

\begin{tabular}{|c|c|c|c|c|c|}
\hline \multirow{2}{*}{$\begin{array}{l}\text { Name of } \\
\text { WQPs }\end{array}$} & $\begin{array}{l}\text { Sensor's } \\
\text { Name }\end{array}$ & \multicolumn{2}{|c|}{ Algorithm } & \multirow[t]{2}{*}{ Applicability } & \multirow[t]{2}{*}{ Reference } \\
\hline & MERIS & Name & Band transformation & & \\
\hline \multirow[t]{7}{*}{ Chl-a } & & Ratio & $\mathrm{b} 7 / \mathrm{b} 9$ & turbid waters with high biomass & [26] \\
\hline & & Three band & $\left(b 7^{-1}-b 9^{-1}\right) \times b 10$ & turbid and hypertrophic waters & [27] \\
\hline & & $\begin{array}{l}\text { Reflectance } \\
\text { Line Height }\end{array}$ & $\begin{array}{l}\mathrm{b} 8-\mathrm{b} 9-\left((\mathrm{b} 10-\mathrm{b} 9)^{*}\left(\Lambda_{\mathrm{b} 9}\right.\right. \\
\left.\left.\quad-\Lambda_{\mathrm{b}} \mathrm{s}\right) \times\left(\Lambda_{\mathrm{b} 10}-\kappa_{\mathrm{b} 9}\right)^{-1}\right)\end{array}$ & turbid and hypertrophic waters & [28] \\
\hline & Landsat & Ratio & $\mathrm{b} 1 / \mathrm{b} 2$ & Chloropyll concentration $<20 \mu \mathrm{g} . \mathrm{l}^{-1}$ & [29] \\
\hline & & & $(\mathrm{b} 1-\mathrm{b} 3) / \mathrm{b} 2$ & $\begin{array}{l}\text { in the presence of suspended sedi- } \\
\text { ment scattering }\end{array}$ & [30] \\
\hline & & & b1/b3 & \multirow[t]{2}{*}{ Chloropyll concentration $>20 \mu \mathrm{g} . \mathrm{l}^{-1}$} & [31] \\
\hline & & & $\mathrm{b} 3 / \mathrm{b} 4$ & & [32] \\
\hline PC & MERIS & Ratio & b9/b6 & turbid inland waters & [33] \\
\hline
\end{tabular}


The spectral resolutions of MERIS and Landsat are suitable for the retrieval of Chl-a, with MERIS proving the better choice for estimating this parameter in turbid inland waters. Band ratios, three band and Reflectance line height algorithms allow Chl-a estimation in turbid waters, ranging from high biomass to hypertrophic waters. For TM/ETM+, various band ratio algorithms have been found suitable for estimating $\mathrm{Chl}$ in turbid waters present in various concentration ranges. A combination of the ratio of the three visible bands allows estimation of Chl-a with minimum influence from the presence of suspended sediment [30].

The finer spectral resolution of MERIS imagery is only suitable for retrieving PC concentrations. However, other algorithms are available for PC estimation with minimum interference from $\mathrm{Chl}$ pigments. These algorithms involve combinations of bands with wavelengths centred close to that of the MERIS bands. For example, some studies [34] show that R (700) / R (600) allows retrieval of PC with negligible influence from Chl pigments. In this study a correlation analysis will be used to find the best band combinations within the red and near IR spectrum.

The wide bandwidths and low signal to noise ratio of TM/ETM+ does not meet the minimum requirements for PC detection [8], however it was found that multiple linear regression of visible to near IR bands was capable of detecting PC $(r 2<0.78)$ [33]. MODIS $500 \mathrm{~m}$ band images also had limited application for the estimation of bio-optical parameters. However, MODIS 500m images may be spectrally comparable to the TM/ETM+ images because their visible and near IR bands fall within the broad wavelengths of TM/ETM+ (Table 4). In this study simple linear and multiple linear regression analyses would be investigated to develop algorithms for MODIS and TM/ETM+.

Table 4. Wavelength comparison for MODIS 500m bands and TM/ETM+ bands

\begin{tabular}{|c|c|c|c|c|c|c|}
\hline \multirow{2}{*}{ Sensor Name } & \multicolumn{6}{|c|}{ Band wave length(nm) } \\
\cline { 2 - 7 } & Blue & Green & Red & NIR & MIR & SWIR \\
\hline MODIS & $459-479$ & $545-565$ & $620-670$ & $841-876$ & $1628-1652$ & $2105-2155$ \\
\hline TM and ETM+ & $450-520$ & $520-600$ & $630-690$ & $760-900$ & $1550-750$ & $2080-2350$ \\
\hline
\end{tabular}

The WQP algorithm development and verification involved five basic steps [24], which include:

- Extraction of image data over the sample sites: The average pixel value for a $3 \times 3$ to $5 \times 5$ pixel window around the sample site would be taken as the representative image value for TM/ETM+ images to reduce random noise [36]. However, a single pixel would be used for MODIS and MERIS due to their coarser spatial resolution relative to TM/ETM+ images.

- $\quad$ Filtering out noisy pixel data: For moderate resolution satellites, at the scan edge the projection of a MODIS and MERIS detector's instantaneous field of view (IFOV) onto the earth's surface is approximately 2.0 and 4.8 times larger than at nadir in the track and scan directions, respectively [37]. The larger pixel size (approximately $2 \mathrm{~km} \times 4.8$ $\mathrm{km}$ ) would significantly reduce the correlation between image data and field measured WQP data. Therefore, pixels at the edge of the swath would be excluded from the analysis.

- Image band transformations: Image bands and transformation of image band combinations that most accurately retrieve Chl-a, PC and turbidity by MERIS, MODIS and TM/ ETM+ as reported in literature (Table 3) would be applied.

- Correlation analysis: Identify image band combinations and their transformations that show the highest correlation with the observed WQP.

- Development and verification of the WQP algorithm: The relationship between a WQP and remotely sensed data would be modelled with linear regressions. Data points withheld from the regressions, served as test data to verify the algorithm and to visualise the robustness using scatter plots. 


\subsection{Generation of a WQP Map from the Image}

The optical properties of inland water are very complex, which is a function of at least 3 optically active in-water constituents.

Normally, empirical algorithms can be expected to perform well only inside their range of derivation and the water type of a specific optical property for which they are derived. The application of the algorithm to another water type with different optical properties would lead to increased error in the estimation of WQPs ([8], and [38]). The application of the algorithm to accurately estimate $W Q P$ requires spatially mapping the optical property as a water type map from this image.

The spectrally stratified WQP mapping technique is proposed by this study to improve the accuracy of estimation. This involves mapping the water type and utilising it as a guide to apply the WQP algorithm for generating an accurate WQP map from the image.

The spatial variability of the spectral properties of waters in the study area is planned to be mapped as water types using a spectral image classification technique, which involves the following procedures:

- The selection of a suitable band and combination of band transformations which spectrally enhances the spatial variability of the optical properties of waters in the study area.

- Apply unsupervised classifications to generate large a number of homogeneous classes.

- Aggregate the classes into a group by analysing the spectral and spatial similarities between them and using available field information to label these groups with an appropriate water type name based on the composition of active in-water constituents.

\section{Results and Discussions}

Archived samples of Chl-a, PC, turbidity and temperature of 2009 and 2010 algal bloom events as shown in Table 5 were obtained for this study. The NOWPS and the MDBA long term datasets: MDBA DSE and MDBA_NOW provide biophysical WQ information across all alert zones from the 2009 algal bloom event that occurred downstream of the Hume Dam to the Yarrawonga Weir (Figure 2). A large volume of observations (38800) from MDBAPS contains biophysical WQ information for the whole of the Hume Dam acquired between $10^{\text {th }}$ and $12^{\text {th }}$ March 2010, largely between a few centimetres to a few meters spacing when the bloom was at its peak [5].

Table 5. Available archive of field sampled WQP data

\begin{tabular}{|c|c|c|c|c|}
\hline Agency Name & $\begin{array}{l}\text { Date of ac- } \\
\text { quisition }\end{array}$ & Location & WQP measured & Number of observations \\
\hline NOWPS & \multirow[t]{4}{*}{$\begin{array}{l}\text { November } \\
2008 \text { to } \\
\text { May } 2009\end{array}$} & $\begin{array}{c}\text { Downstrean of Yarra- } \\
\text { wonga Weir to Murray } \\
\text { River at Albury (Union } \\
\text { Bridge) }\end{array}$ & $\begin{array}{l}\text { Chl-a, PC, Turbidity, } \\
\text { Temperature }\end{array}$ & $\begin{array}{c}2-5 \text { taken at } 21 \text { different } \\
\text { days }\end{array}$ \\
\hline $\begin{array}{l}\text { MDBA long } \\
\text { term sampling }\end{array}$ & & & & \\
\hline MDBA_DSE & & $\begin{array}{l}\text { River Murray at Hey- } \\
\text { woods (409016) }\end{array}$ & Chl-a and Turbidity & $\begin{array}{c}1 \text { taken at } 16 \text { different } \\
\text { days }\end{array}$ \\
\hline MDBA_NOW & & $\begin{array}{l}\text { Downstream of Yarra- } \\
\text { wonga Weir (409025) }\end{array}$ & Chl-a and Turbidity & $\begin{array}{c}1 \text { taken at } 30 \text { different } \\
\text { days }\end{array}$ \\
\hline MDBAPS & $\begin{array}{c}10-12 \\
\text { March } 2010\end{array}$ & Hume Dam & $\begin{array}{l}\text { PC, Turbidity, Temper- } \\
\text { ature }\end{array}$ & 38800 taken in 3 days \\
\hline
\end{tabular}


The site-wise scatterplot distribution of Chl-a vs PC of the NOWPS dataset (Figures $2 \mathrm{a} \& 2 \mathrm{~b})$ depicts more temporal than spatial variability. The waters at Yarrawonga Weir sites have relatively low Chl-a concentrations $\left(<13 \mu \mathrm{g} . \mathrm{l}^{-1}\right)$ compared to sites at River Murray. The Yarrawonga Weir and the Murray River sites both show the occurrence of two types of Chl-a vs PC compositions, one is showing a condition dominated by Cyanobacteria where PC is found to increase with Chl-a concentrations and is representative of a Cyanobacterial bloom. The other composition shows high Chl-a concentrations associated with relatively low PC concentrations ( $\leq 1.25 \mathrm{RFU})$, which is indicative of conditions prior to or after an algal bloom. In this condition, the optical property is different from that in Cyanobacteria dominated conditions as shown in PC vs. Turbidity scatterplot (Figures 2c and $2 \mathrm{~d}$ ). For the same $\mathrm{Chl}$ concentration level, the turbidity is higher in this condition than in Cyanobacteria dominated conditions. This may be because the effect of PC absorption on turbidity is less in this condition than in Cyanobacteria dominated conditions.

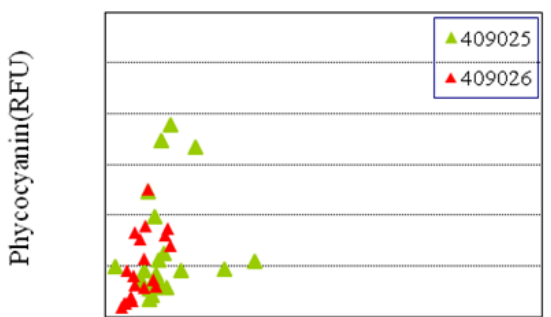

Chrophyll-a concentration $\left(\mathrm{g} . \mathrm{l}^{-1}\right)$

a) for sites in the Yarrawonga Weir

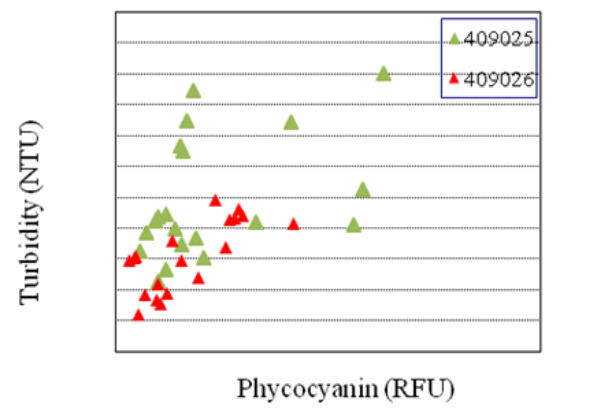

c) for sites in the Yarrawonga Weir

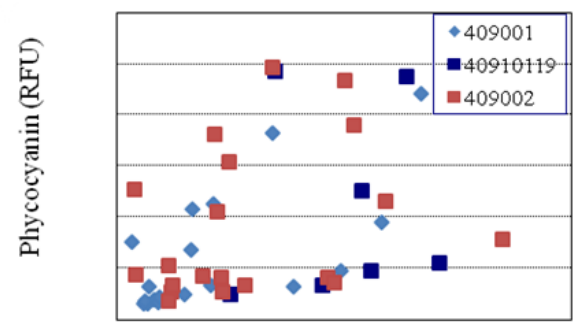

Cholorophyll-a concentration $\left(\mu \mathrm{g} . \mathrm{l}^{-1}\right)$

b) for sites in the Murray River

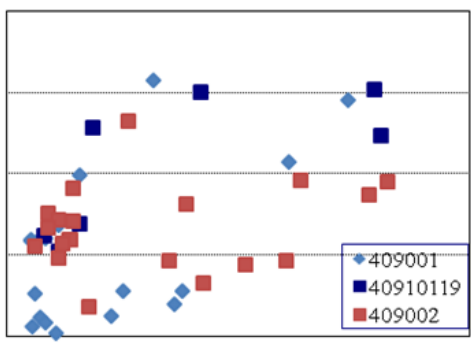

Phycocyanin (RFU)

d) for sites in the Murray River

Figure 2. Scatter plot Turbidity vs. Chl-a

The NOWPS dataset successfully captured the temporal variability of water quality across the 2009 cyanobacterial bloom as shown by the scatterplot of Chl-a vs PC and PC vs. Turbidity (Figures $3 a$ and $3 b$ ). In these plots, the sampled data is grouped as pre-bloom during and post-bloom, taking the period of the algal bloom to be between the middle of February to the middle of April. The pre-bloom data shows low PC $(<1$ RFU) and relatively low Chl-a concentrations $\left(<10 \mu \mathrm{g} .1^{-1}\right)$, while post-bloom data shows low PC $(<2.5$ RFU) and relatively high Chl-a concentrations (10-30 $\left.\mu \mathrm{g} \cdot \mathrm{l}^{-1}\right)$. Data during the period of the algal bloom us shows an increase of both PC and Chl-a concentrations (Figure 3a). The rising rate of turbidity due to the increase of Chl-a during pre and post bloom periods is higher than that seen during the bloom period (Figure 3b). The scatter plot of Chl-a vs. Turbidity (Figure 3c) shows that the change in turbidity is influenced more by the presence of Chl-a than the presence of PC, and fails to distinguish between bloom and postbloom conditions where high Chl concentrations (10-30 $\left.\mu \mathrm{g} . \mathrm{l}^{-1}\right)$ and low PC levels are found. This result suggests that PC is a more important parameter than Chl-a for detecting cyanobacterial blooms. 


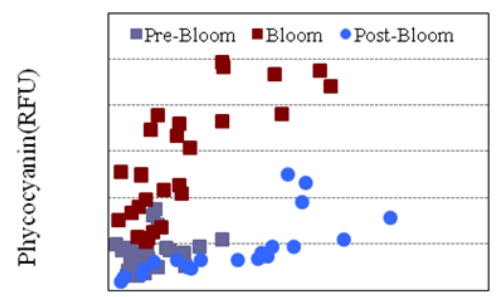

Cholorophyll-a concentration $\left(\mu \mathrm{g} \cdot \mathrm{l}^{-1}\right)$

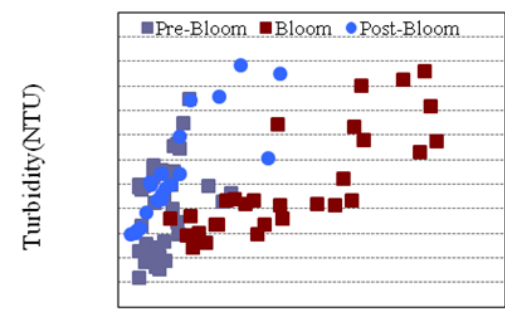

Phycocyanin(RFU)

a) Chl-a vs. PC

b) PC vs. Turbidity

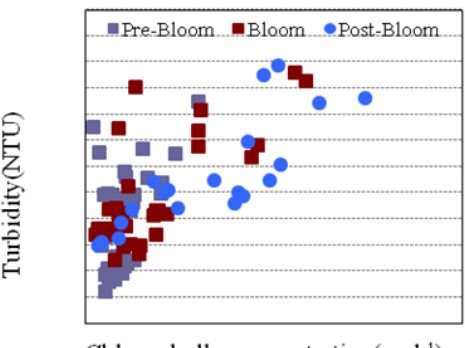

Chlorophyll-a concentration $\left(\mu \mathrm{g}, \mathrm{l}^{-1}\right)$

c) Chl-a vs. Turbidity

Figure 3. Scatter plots of period of algal bloom between middle of February and the middle of April.

Comparison of Chl-a vs. turbidity scatterplots of NOWPS data and MDBA long term data as shown in Figures $4 \mathrm{a}$ and $4 \mathrm{~b}$ suggests that only the MDBA_DSE data is suitable to be used collectively with the NOWPS data. The distributions of NOWPS data and MDBA_DSE data are similar (Figure 4a). The higher Chl concentrations $\left(>30 \mu \mathrm{g} .1^{-1}\right.$ ) of MDBA_DSE data relative to NOWPS data agrees with fact that it is sampled from the site (site\# 409016) at Heywood which is located further upstream of the NOWPS sites (site\# 409001, 4091011 409002) and is closest to the point of discharge from the Hume Dam where algal was first detected in March 2009[2] as shown in Figure 4.

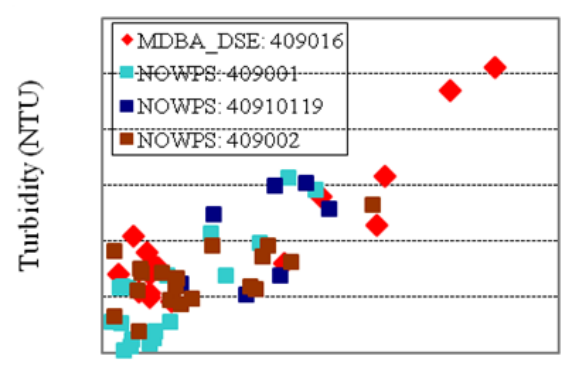

Chlorophyll-a concentration $\left(\mu \mathrm{g} . \mathrm{l}^{-1}\right)$

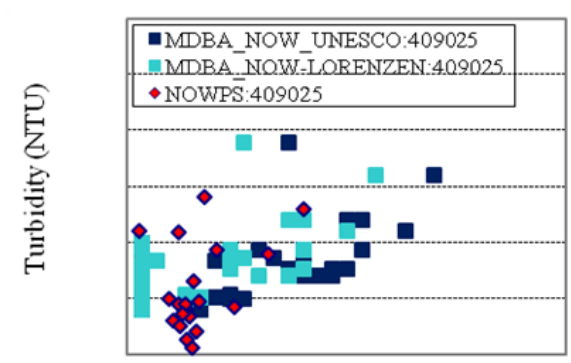

Chlorophyll-a concentration $\left(\mu \mathrm{g} . \mathrm{l}^{-1}\right)$

b) NOWPS and MDBA_NOW datasets

a) NOWPS and MDBA_DSE datasets

Figure 4. Comparison of scatter plots of Chl-a vs. Turbidity.

The distribution of MDBA_NOW data and NOWPS data are not similar (Figure 4b) even though these data sets are sampled from the same site (409025). This dissimilarity is resulting from the difference in Chl-measurement techniques. The UNESCO [11] and Lorenzen[12] spectro-photometric techniques overestimates Chl-a concentrations $\left(\mu \mathrm{g} .1^{-1}\right)$ compared to the Flourometric technique used by NOWPS. 
The scatter plot distribution of PC vs. turbidity of the complete MDBAPS dataset of Hume Dam, as shown in Figure 5, is very complex and it is difficult to interpret the relationship between spatial variability of bio-optical parameters and their optical properties. The field sample acquisition path was segmented into various East to West and North to South transects and analysis of scatter plot distribution of PC vs. turbidity for each of these transects and their groups as Northern Zone (NZ), Dam Wall Zone (DWZ), Southern Zone (SZ) and Southern Most Zone (SMZ) is shown in Figure 6. Analysis of scatter plot distribution of PC vs. turbidity for each of these transects show that the data consists of $20-30 \%$ of outliers (Figure 7a) and good data sets (Figure 7b). The outliers are distributed rather randomly compared to the good data set. This data set has a distribution similar to that of scatter plot PC vs. turbidity of NOWPS data showing the effect of co-variation of Chlorophyll and PC on turbidity at pre-bloom, bloom and post-bloom conditions observed during the 2009 bloom event (Figure 3b). In the absence of chlorophyll measurement, the information of the relationship of co-variation of Chlorophyll and PC with turbidity as observed during this event may be used to infer about the spatial distribution of chlorophyll at the peak of an algal bloom event on 10 March 2010 in the Hume Dam.

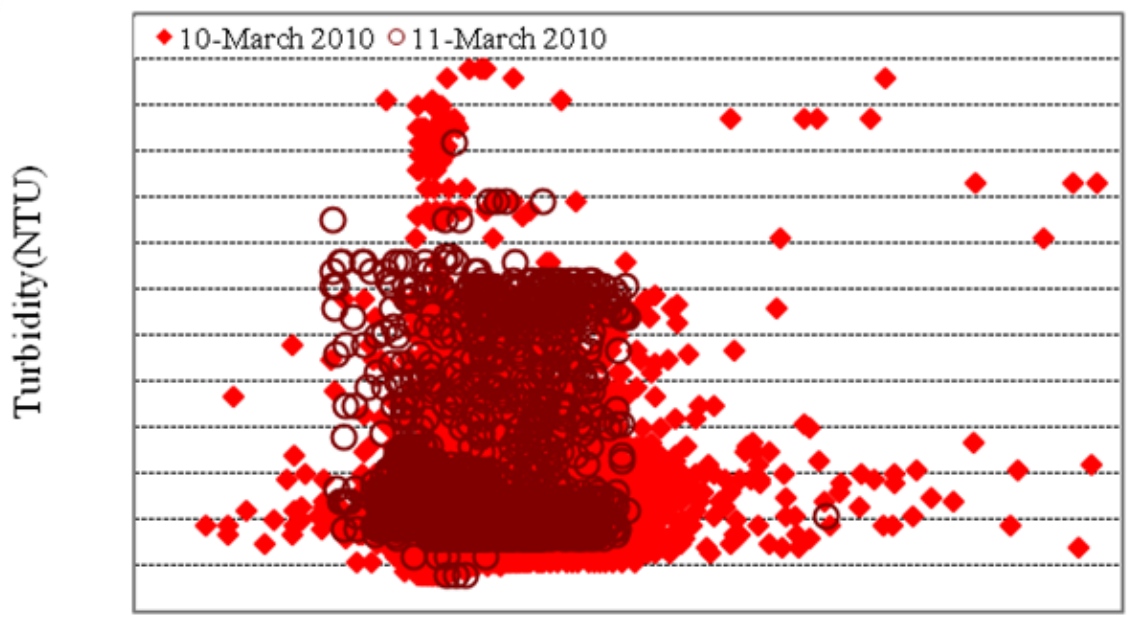

Phycocyanin (Cells ml ${ }^{-1}$ )

Figure 5. Scatter plot of PC vs. Turbidity of the MDBA dataset.

The zone-wise scatterplot distributions of PC vs. turbidity of good data set show the effect of spatial co-variation of Chlorophyll and PC on turbidity in the Hume Dam. These distributions are in conformity with the spatial distribution gradient of NOW field measurements of blue green algae of 10/03/2012 at three sites with one at Dam wall and other two with one in its South at Ebden and its North at Heywood (Figure 6). The Phycocyanin concentration is higher at Ebden and Heywood than the Dam wall with highest concentrations at Heywood (Figure 7). The Phycocyanin concentration is also found to be higher in the Southern Most Zone (SMZ) than those of Dam Wall Zone (DWZ) but with a dip in concentrations in SZ in between SMZ and DWZ. However, even though in the north the concentration in NZ is lower than those of DWZ, the concentrations decrease in the North to South direction in NZ (Figure 8) suggesting that the Phycocyanin concentrations of waters further north of Transect 1 and 2 at Heywood may be higher than those of DWZ. 


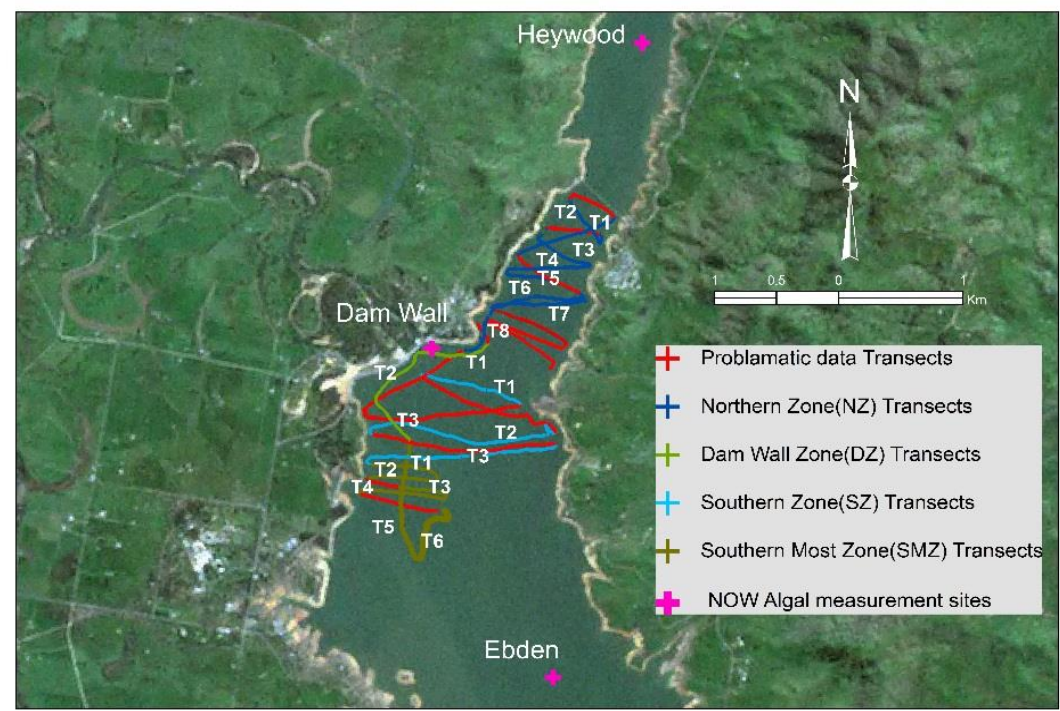

Figure 6. Segmentation and grouping of acquisition path into various East to West and North to South transects.

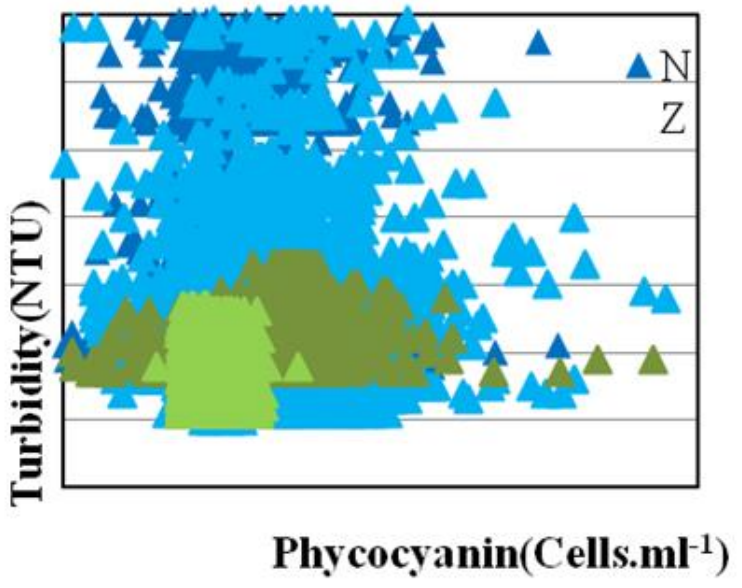

a) Problematic data

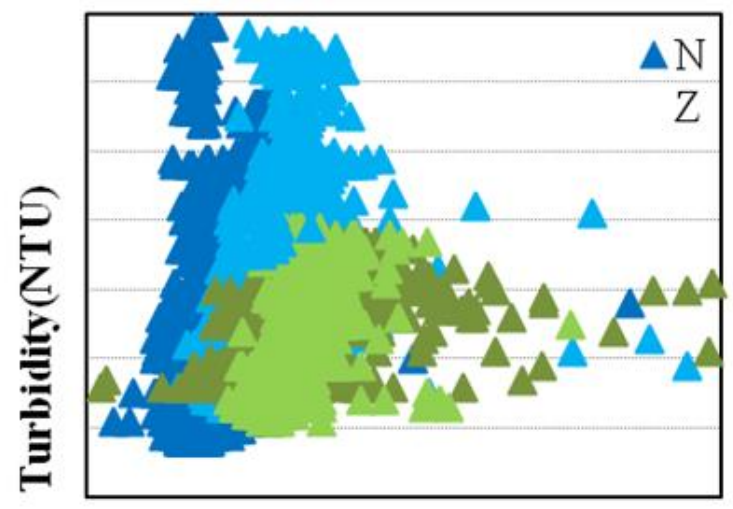

Phycocyanin(Cells.ml-1)

Figure 7. Zone-wise scatterplot of Phycocyanin vs. Turbidity(The abreviations NZ, SZ, SMZ and DWZ refer to Northern Zone, Southern Zone, Southern Most Zone and Dam Wall Zone respectively).

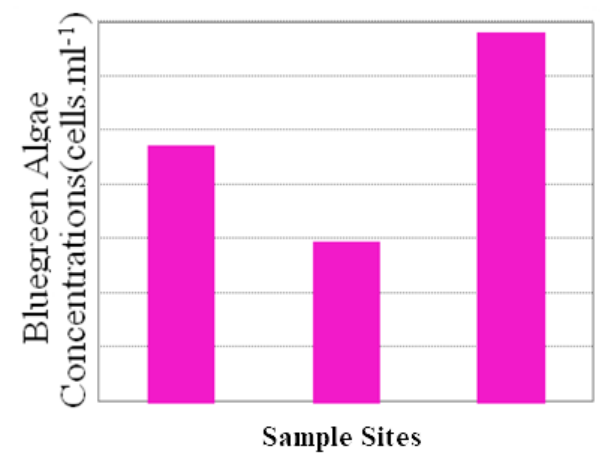

Figure 8. Bluegreen algae concentrations (Cell.ml-1) determined on 10/03/2010 at sample sites Ebden, Dam Wall and Heywood in the Hume Lake (see Figure 6 for site locations). 


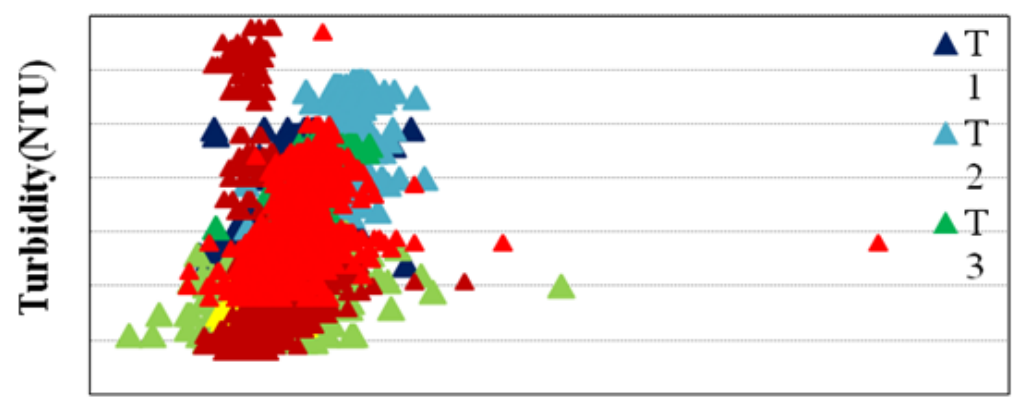

Phycocyanin(Cells.ml $\left.{ }^{-1}\right)$

Figure 9. Transect-wise scatterplot of Phycocyanin vs. Turbidity in Northern Zone(NZ) with Transects 1 and 2 are furthest with respect to the Dam Wall Zone(DWZ).

Samples are taken from Eastern Side (ES), Western Side (WS) and in between (IB) ES and WS of each transects as shown in the Figure 10 for comparing East to West distributions. The scatterplot distributions of PC vs. Turbidity spatial variation of chlorophyll concentrations may be inferred only from the first three transects. The concentrations only of first three transects in NZ are higher in the Western side than in the Eastern side (Figure 11) and from the fourth segment onward the concentration gradient shifts and the concentrations in the Eastern side becomes higher than in the Western side as shown in Figure 12. Transects 1 and 2 show that even though the samples of Transect 1 in the Eastern Side (ES) are closest to the bridge in the north than the samples of Transect 2 in the Western Side (WS) (Figure 10), the samples of transect 2 in the WS show both higher Phycocyanin and turbidity than those of Transect 2 in the ES (Figure 11a). This suggests that both chlorophyll and PC concentrations are higher in the WS than in the ES. The same is observed between Transect 2 and 3 distributions. Both Phycocyanin and turbidity are higher in the WS of Transect 3 than those in the ES of Transect 2(11b). Both of these parameters decrease from Transect 1 to Transect 3 in the North to South direction at higher magnitude in the WS than in the ES.

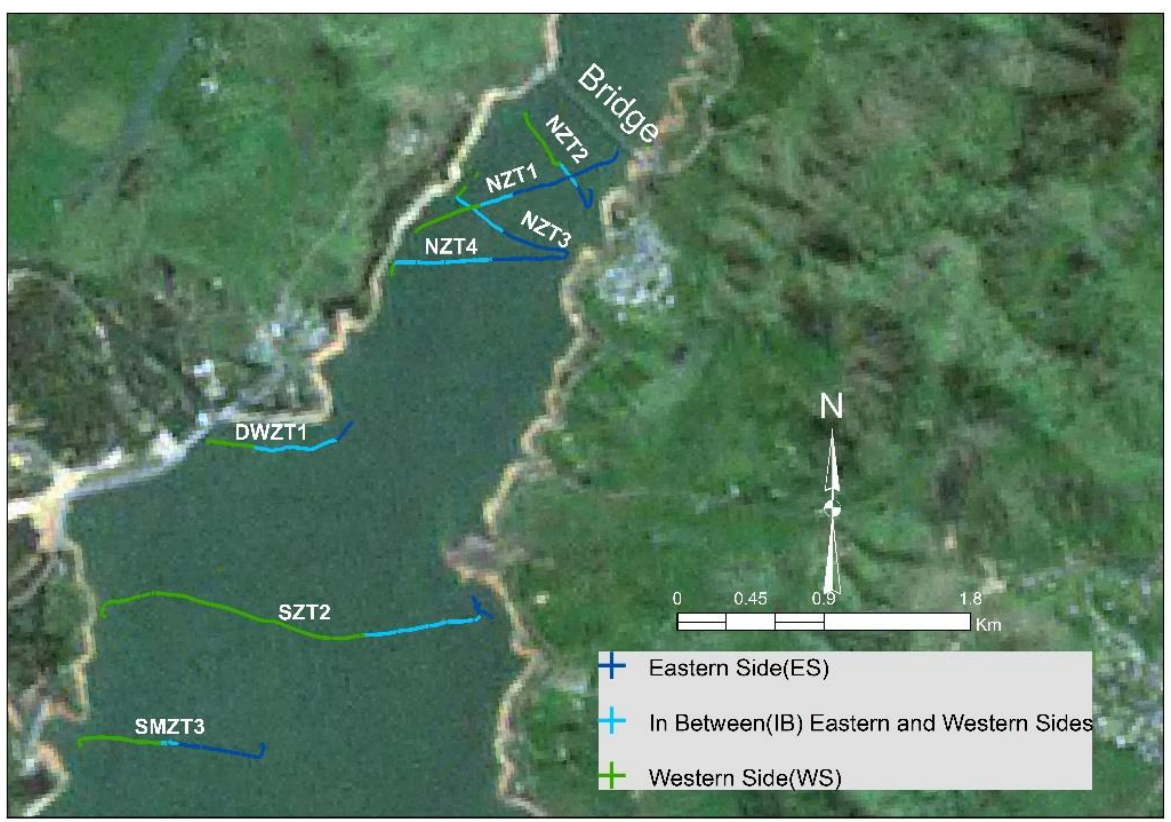

Figure 10. Map of samples of Eastern Side (ES), Western Side (WS) and In Between (IB) ES and WS taken from selected transects for comparison of East to West distributions. 


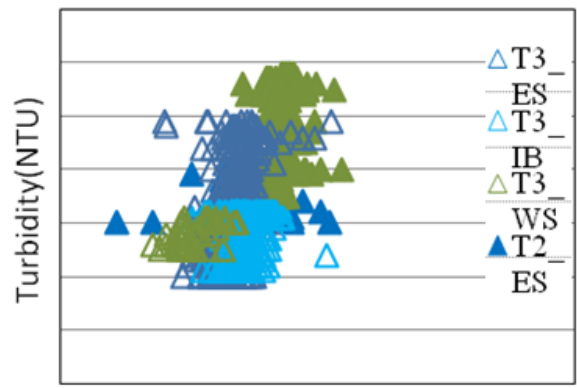

Phycocyanin $\left(\right.$ Cells.mll $\left.{ }^{-1}\right)$

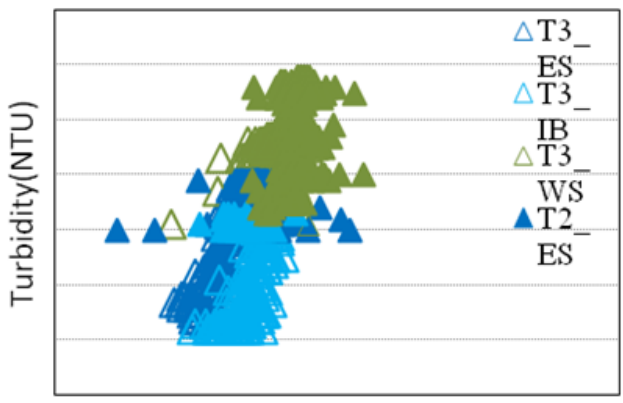

Phycocyanin $\left(\right.$ Cells $\left.\cdot \mathrm{ml}^{-1}\right)$

Figure 11. Scatterplot distributions of Eastern Side (ES), Western Side(WS) and In Between(IB) ES and WS samples of: a) Transects 1 and 2; and b) Transects 2 and 3.

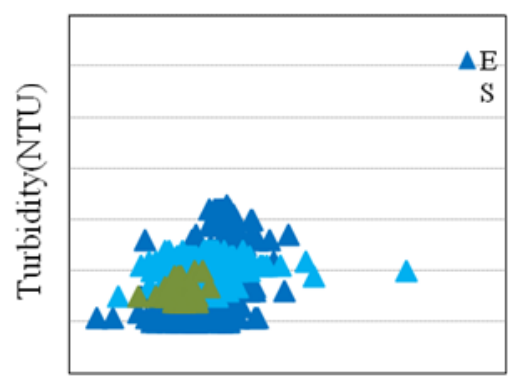

Phycocyanin (Cells. $\left.\mathrm{ml}^{-1}\right)$

a) Transect 4, Northern Zone(NZ)

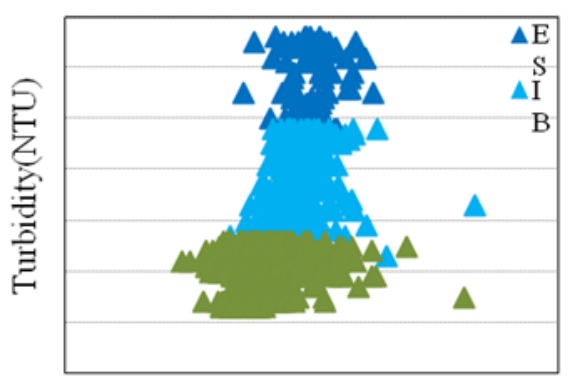

Phycocyanin $\left(\right.$ Cells. $\left.\mathrm{ml}^{-1}\right)$

c) Transect 1 , Southern Zone(NZ)

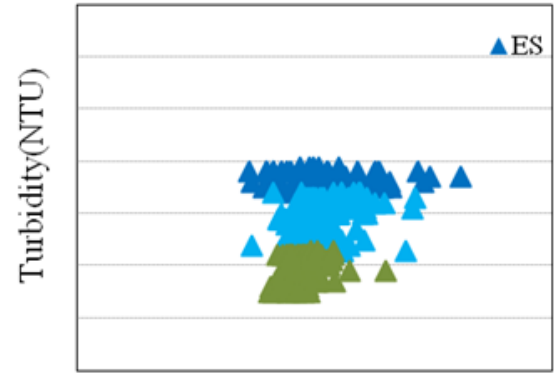

Phycocyanin (Cells. $\left.\mathrm{ml}^{-1}\right)$

b) Transect 1, Dam Wall Zone(DWZ)

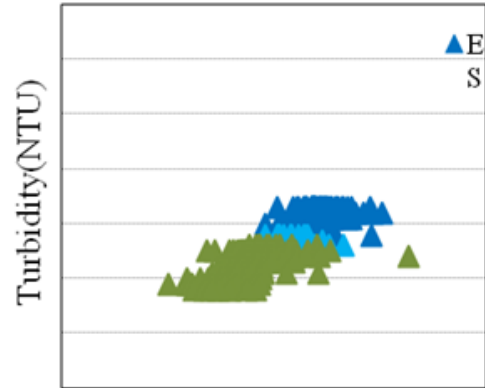

Phycocyanin $\left(\right.$ Cells $\left.\cdot \mathrm{ml}^{-1}\right)$

d) Transect 1, Souther Most Zone(SMZ)

Figure 12. Scatterplot distributions of Eastern Side (ES), Western Side (WS) and In Between (IB) ES and WS samples of: a) Transects 4 (NZ)and 2; b) Transects 1 DWZ; c) b) Transects 1 SZ; and d) Transects 1 SMZ.

\section{Conclusions}

Archived, field sampled datasets were available for Cyanobacterial bloom events that occurred in 2009 and 2010 in the study area. For the 2009 event, data was available from across the bloom event for sites between the Murray River downstream of Hume Dam to the Yarrawonga Weir. For the 2010 event, field samples were available during the peak of the bloom in the Hume Dam. The findings and the way forward are summaised here:

- Analysis of the 2009 data shows that waters in sites in the Murray River downstream of the Hume Dam to the Yarrawonga Weir show more temporal than spatial varia- 
bility in Chl-a and PC levels. The Chl-a concentration is relatively less in the Yarrawonga Weir than in the Murray River. The scatter plot of PC vs. Turbidity suggests that $\mathrm{PC}$ is a more significant parameter for the detection of Cyanobacteria than Chla.

- $\quad$ Analysis of the data shows that potential exists to test the Remotely Sensed WQP monitoring technique, provided an adequate number of archived satellite images are available close to its acquisition dates. The 2009 data of the NOW pilot study [4] is suitable for testing the spatial technique for a complete single algal bloom event. The field data represents the temporal bio-optical variability across the 2009 algal bloom events by successfully capturing the co-variations among Chlorophyll-a, Chycocyanin and turbidity at pre, during and post bloom conditions.

- $\quad$ The long term MDBA RMWQMP data for the 2009 bloom event is found partially compatible to the NOW Pilot study data in that only the data for the Heywood site can be used together for testing the WQP monitoring technique. The incompatibility of the RMWQMP data downstream of Yarrawonga Weir may be due to differing techniques used for determining Chlorophyll.

- The 2010 data is suitable for testing the technique for complex spatial bio-optical variability during the peak of the bloom in a large water storage. Lack of Chlorophyll measurements in 2010 data poses challenges in interpreting the relationship of biooptical variability with the spatial distributions of bio-optical parameters. As relational parameters are absent, local information and expert advice will be required to develop plausible assumptions between the Chlorophyll - Phycocyanin relationship.

- The field sampled data for the 2010 bloom event acquired from the Hume Dam may be used for further comparative investigation of both moderate resolution sensors (MODIS and MERIS) and high-resolution sensors (TM/TM+). The 2009 bloom event field samples of sites in the Yarrawonga Weir may be used as an input with MODIS and MERIS and the data from all the sites can be used with TM/TM+.

\section{Acknowledgements}

We would like to express our gratitude to all those MDBA colleagues and state governments who assisted in provision of data, advice and support to conduct this project. The authors are also grateful to Professor Arlnold Dekker of CSIRO's Earth Observation Informatics Future Science Platform and anonymous reviewers for their valuable comments and feedback on the manuscript. The views expressed in this paper are the authors' and not necessarily the views of their organisation.

\section{References}

[1] Nixon, Scott W., “Coastal marine eutrophication-A definition, social causes, and future concerns”, Ophelia 41, 1995, pp. 199-219.

[2] Ryan, N.J., Dabovic, J., Bowling, L.D., Driver, B. and Barnes, B., “The Murray River Algal Bloom: evaluation and recommendations for the future management of major outbreaks", NSW Office of Water, 2009, pp. 1-41.

[3] Baldwin, D.S., "Influence of extreme drawdown on water quality downstream of a large water storage reservoir", River Research and Applications, 2009.

[4] Baldwin, D.S., Gigney, H., Wilson, J.S., Watson, G. and Boulding, A.N., “Drivers of water quality in a large water storage reservoir during a period of extreme drawdown", Water Research, Vol. 42, No. 19, 2008, pp. 4711-4724.

[5] Kleeman, K., Vanner, M., Merrick, C., and Bowling, L., "Poster: Inter-Agency Response to the 2010 Cyanobacterial Bloom in the Murray River", Cyanobacteria in Australia-Bloom Management, Research and Future Options. Abstracts from the second National Cyanobacterial Workshop, 2010, pp. 64.

[6] Shafique, N.A., Autrey, B.C., Fulk, F. and Cormier, S.M.," Hyperspectral narrow wavebands selection for optimizing g water quality monitoring on the Great Miami River, Ohio", Journal of Spatial Hydrology, Vol. 1, No. 1, 2001, pp. 1-22.

[7] Eugenio, F., Marcello, J., and Martín, J., "Multiplatform Earth Observation Systems for Monitoring Water Quality in Vulnerable Inland Ecosystems: Maspalomas Water Lagoon", Remote Sensing 2020, 12, 284. https://doi.org/10.3390/rs12020284.

[8] Ambrose-Igho, G., Seyoum, W.M., Perry, W., \& O’Reilly, C.M., "Spatiotemporal Analysis of Water Quality Indicators in Small Lakes Using Sentinel-2 Satellite Data: Lake Bloomington and Evergreen Lake, Central Illinois, USA", Environmental Processes (2021), https://doi.org/10.1007/s40710-021-00519-x (accessed 30 April 2021). 
[9] Matthews, M. W., "A current review of empirical procedures of remote sensing in inland and near-coastal transitional waters", International Journal of Remote Sensing, Vol.32, No. 21, 2011, pp. 1-45.

[10] Dekker, A., Peters, S., Vos R., and Rijkeboer, M., "Remote sensing for inland water quality detection and monitoring: State-ofthe-art application in Friesland waters", GIS and Remote Sensing Techniques in Land-and Water-management, Netherlands: Kluwer Academic Publisher, 2001.

[11] UNESCO, "Monograph on oceanographic methodology - Determination of photosynthetic pigments in sea water", United Nations Educational, Scientific and Cultural Organization, Paris, 1966.

[12] Lorenzen, C.J, “Determination of Chl and phaeo-pigments: spectrophotometric equations. Limnology Oceanography, Vol. 12, No. 3, 1967, pp. 343-346.

[13] ASTM International, “D1889-00 Standard test method for turbidity of water, in ASTM International, Annual Book of ASTM Standards", Water and Environmental Technology, v. 11.01, West Conshohocken, Pennsylvania, 2003, 6 pp.

[14] IOCCG, "Remote sensing of ocean colour in coastal, and other optically-complex, waters", In Reports of the International OceanColour Coordinating Group, No. 3, Sathyendranath, S. (Ed.), Dartmouth, NS: IOCCG, pp. 1-140, 2000.

[15] Harris, G.P., "Nutrient loadings and algal blooms in Australian waters - a discussion Paper", LWRRDC Occasional Paper, No. 12/94, 1994, $99 \mathrm{pp}$.

[16] NASA MODIS web Specification, Available online at: http://modis.gsfc.nasa.gov/about/specifications.php (accessed 2 November 2011).

[17] Doxaran, D., Froidefond, J.M., Castaing, P. and Babin, M., "Dynamics of the turbidity maximum zone in a macrotidal estuary (the Gironde, France): observations from field and MODIS satellite data", Estuarine, Coastal and Shelf Science, 81, No. 3, 2009, pp. 321-332.

[18] Petus, C., Chust, G., Gohin, F., Doxaran, D., Froidefond, J.M. and Sagarminaga, Y., “Estimating turbidity and total suspended matter in the Adour River plume (South Bay of Biscay) using MODIS 250-m imagery", Continental Shelf Research, Vol. 30, No. 5, 2010, pp. 379-392.

[19] Hellweger, F.L., Schlosser, P., Lall, U., and Weissel, J.K., “Use of satellite imagery for water quality studies in New York Harbor”, Estuarine, Coastal and Shelf Science, Vol. 61, No. 3, 2004, pp. 437-448.

[20] Wong, M. S., Nichol, J. E., Lee, K. H., and Emerson N, “Modeling Water Quality using TERRA/MODIS 500m satellite images”, The International Archives of the Photogrammetry, Remote Sensing and Spatial Information Sciences, Vol. XXXVII. Part B8. Beijing, 2008, pp. 679-684.

[21] Shutler, J. D., Land, P. E., Smyth, T. J. and Groom S. B., “Extending the MODIS $1 \mathrm{~km}$ ocean colour atmospheric correction to the MODIS 500m bands and 500m Chl-a estimation towards coastal and estuarine monitoring", Remote Sensing of Environment, Vol. 107, No. 4, 2007, pp. 521-532.

[22] Kahru, M., Mitchell, B.G., Diaz, A., Miura, M., "MODIS Detects a Devastating Algal Bloom in Paracas Bay, Peru", EOS, Transactions, American Geophysical Union, Vol. 85, N 45, 2004, pp. 465-472.

[23] NASA, "Landsat 7 Science Data Users' Handbook", Available online at: http://landsathandbook.gsfc.nasa.gov/pdfs/Landsat7_Handbook.pdf (accessed 2 November 2011).

[24] Islam, A., Wang, L., Smith, C., Reddy, S., Lewis, and Smith, A., “Evaluation of satellite remote sensing for operational monitoring of sediment plumes produced by dredging at Hay Point, Queensland, Australia", Journal of Applied Remote Sensing, Vol. 1, 011506, 2007, 15 pp.

[25] Li, F., Reddy S., Lymburner, L., Muller, N., Tan, P. Islam, M. A., “An Evaluation of the Use of Atmospheric and BRDF Correction to Standardise Landsat Data", IEEE Journal of Selected Topics in Earth Observations and Remote Sensing, Vol. 3, No. 3, 2010, pp. 257270.

[26] Koponen, S., Attila, J., Pulliainen, J., Kallio, K., Pyhälahti, T., Lindfors, A., Rasmus, K. and Hallikainen, M., “A case study of airborne and satellite remote sensing of a spring bloom event in the Gulf of Finland", Continental Shelf esearch, 27, No. 2, 2007, pp. 228-244.

[27] Moses, W.J., Gitelson, A.A., Berdnikov, S. and Povazhnyy, V., " Satellite estimation of Chl-a concentration using the red and NIR bands of MERIS - the Azov Sea case study", IEEE Geoscience and Remote Sensing Letters, 6, No. 4, 2009 , pp. 845-849.

[28] Moses, W.J., Gitelson, A.A., Berdnikov, S. and Povazhnyy, V., "Estimation of Chl-a concentration in case II waters using MODIS and MERIS data - successes and challenges", Environmental Research Letters, 4, 045005, 2009, 8pp.

[29] Cipollini, P. and Corsini, G., and Ferretti, E., "Multitemporal water quality analysis along the Ligurian Coast", In Proceedings of the IGARSS 93 Symposium, Piscataway, NJ, USA, (IEEE cat n 93ch3294-6), Vol. 2, 1993, pp.700-702.

[30] Brivio, P. A., Giardino, C., and Zilioli, E, "Determination of Chl concentration changes in Lake Garda using an image-based radiative transfer code for Landsat TM images", International Journal of Remote Sensing, Vol. 22, No. 2-3, 2001 , pp. 487-502.

[31] Mishra, S., Mishra, D.R. and Schluchter, W.M., “A novel algorithm for predicting PC concentrations in cyanobacteria: a proximal hyperspectral remote sensing approach", Remote Sensing, 1, No. 4, 2009, pp. 758-775.

[32] Vincent, R.K., Qin, X.M., Mckay, R.M.L., Miner, J., Czajkowski, K., Savino, J. and Bridgeman, T., "PC detection from LANDSAT TM data for mapping cyanobacterial blooms in Lake Erie", Remote Sensing of Environment, Vol. 89, No. 3, 2004, pp. $381-392$.

[33] Forster, B. C., Xingwei, S., and Baide, X., 1993, "Remote sensing of seawater quality parameters using Landsat TM", International. Journal of Remote Sensing. 14, No. 12, 2759-2771. 
[34] Nishihama, M., Wolfe, R., Solomon, D., Patt, F., Blanchette, J., Fleig, A. and Masuoka, E., “MODIS Level 1A Earth Location: Algorithm Theoretical Basis Document", Version 3.0, MODIS GSFC SBRS, SDST-092, 1997, pp. 3-2.

[35] Islam, M.A., Gao, J., Ahmad W., Neil D., and Bell P., "Image Calibration to Like-Values in Mapping Shallow Water Quality from Multitemporal Data", Photogrammetric Engineering and Remote sensing, Vol. 69, No. 5, 2003, pp. 567-575.

[36] Hussain, M., Al-shaiba, B., Zhang, J., and Liu X., "Modeling Water Quality Parameters Using Landsat Multispectral Images: A Case Study of Erlong Lake, Northeast China". Remote Sensing 13(1603):1-20: DOI:10.3390/rs13091603 (accessed 28 April 2021 ).

[37] Mbongowo J. M, "Use of Hyperspectral Remote Sensing to Estimate Water Quality". Processing and Analysis of Hyperspectral Data, October 2019: DOI:10.5772/intechopen.89222 (accessed 2 May 2021).

[38] Hassan G., Shaheen, M.E., Taie, S.A., "Prediction Framework for Water Quality Parameters Monitoring via Remote Sensing", IEEE Conference, 3-5 Nov. 2020, Riyadh, Saudi Arabia: DOI: 10.1109/SMART-TECH49988.2020.00029 (accessed 6 May 2021).

[39] Han, L. and Jordan, K., "Estimating and mapping Chl a concentration in Pensacola Bay, Florida using Landsat ETM data", International Journal of Remote Sensing, 26, No. 23, 2005, pp. 5245-5254.

[40] Duan, H.T., Zhang, Y.Z., Zhan, B., Song, K.S. and Wang, Z. M.,“Assessment of Chl-a concentration and trophic state for Lake Chagan using Landsat TM and field spectral data", Environmental Monitoring and Assessment, Vol. 129, No, 1-3, 2007, pp. 295308.

[41] Hunter, P.D., Tyler, A.N., Gilvear, D.J., and Willby, N.J., “Using remote sensing to aid the assessment of human health risks from blooms of potentially toxic cyanobacteria", Environmental Science and Technology, 43, 7, 2009, pp. 2627-2633. 